\title{
Cimarrones y palenques en las provincias al norte del Nuevo Reino de Granada siglo XVII
}

\author{
María Cristina Navarrete $\mathbf{P}$. \\ Universidad del Valle
}

\begin{abstract}
Resumen
A finales del siglo XVII, ya existían comunidades de cimarrones en varias provincias de la jurisdicción de la Audiencia del Nuevo Reino de Granada. Hacia 1598, en Zaragoza, y en 1607, en Remedios, provincia de Antioquia, esclavos negros de las rancherías mineras se levantaron violentamente y fortificaron en palenques, causando perjuicios en el comercio, la vida de las ciudades y la labor de las minas. Otro de los más importantes alzamientos de esclavos fue el dirigido por Domingo Biohó quien se refugió con sus seguidores en la Ciénaga de la Matuna. Asimismo, las Sierras de María y la Serranía de San Lucas fueron espacios de establecimiento de palenques. Los cimarrones intentaron reconstruir organizaciones sociales con base en la herencia cultural africana, en la permanencia en las haciendas y minas al contacto con amos, capataces y compañeros de circunstancias $\mathrm{y}$, en las nuevas condiciones que les ofrecía la vida de los palenques.
\end{abstract}

\begin{abstract}
By the end of the 17th century maroon communities existed in several provinces of the jurisdiction of the Audience of New Granada. In 1598 in Zaragoza and in 1607 in Remedios, in the province of Antioquia, black slaves from the mining camps revolted violently and fortified in palenques. They caused interruptions in commerce, village life and the production in mining centers. Another important slave uprising was the one led by Domingo Biohó who sought refuge along with his followers at the lagoon of Matuna. Also, the María and San Lucas Mountains were places in which runaway slaves often settled. The maroons tried to rebuild social organizations based upon African cultural heritage, the time spent in the haciendas and mines in contact with owners, supervisors and fellow friends, and the new conditions offered by the palenques.
\end{abstract}


El cimarronismo, o proceso por medio del cual los esclavos huían de la tutela de sus propietarios, estuvo vigente desde los comienzos de la presencia española en el Nuevo Reino de Granada. Los africanos reaccionaron frente a la esclavitud, escapando del control de sus amos y formando aldeas en espacios de geografía inaccesible, fortificadas, muchas veces, con empalizadas, término del que tomaron el nombre genérico de palenques.

Aunque la información acerca de los palenques es escasa, se tiene por cierto que a finales del siglo XVI, había comunidades de cimarrones en las provincias de Cartagena, Santa Marta y Antioquia. Desde este momento, se convirtieron en un grave problema para la sociedad y para las instituciones gubernamentales de las provincias. Los dueños de los esclavos no sólo perdían su propiedad sino que sufrían la amenaza de los cimarrones que constituían los palenques, especies de comunidades cuasi independientes, desde los cuales se desplazaban a robar y atemorizar a los habitantes de las ciudades, las estancias y las rancherías de minas.

El historiador colombiano Hermes Tovar explica cómo la interiorización de la liberación condujo a los esclavos a posturas radicales que se expresaron en la formación de palenques, en el amotinamiento y en el uso de la violencia. Esta práctica entró en contradicción con las formas jurídicas utilizadas por la mayoría de los esclavos. En general, para conseguir la libertad, los esclavos prefirieron los instrumentos legales más que la fuerza y la violencia. En relación con las diversas formas jurídicas por las que optaron los esclavos para acceder a la ley y a la libertad, el mencionado historiador ordena y sistematiza las que el Estado puso a su disposición. La primera de ellas era la de recurrir a las autoridades para denunciar el incumplimiento de las leyes por parte de los amos. Esta fue una manera de proteger la población esclava. La segunda opción tenía que ver con la posibilidad de los esclavos de solicitar el cambio de propietario y se convirtió casi en un derecho. La tercera posibilidad fue la compra de la libertad mediante el pago de una cifra que se fijaba de acuerdo al valor del esclavo. Dice el autor que: "la compra de la libertad fue más bien un recurso pasivo de los negros, fundamentado sobre la aceptación de su condición.” La cuarta opción fue la liberación espontánea que algunos propietarios concedieron a sus esclavos. Estuvo presente a todo lo largo de la existencia de la esclavitud en los territorios de Indias. La quinta, la más radical de ellas, no reconocida por la ley, estaba vinculada al deseo de conseguir la propia libertad arrebatándola al Estado y a los amos, mediante la fuga. Esta alternativa, 
conocida como cimarronismo, no se limitó a la formación de palenques sino a la necesidad de crear estructuras sociales por la vía clandestina. ${ }^{1}$

A pesar de que la creación de palenques fue una opción que asumieron los esclavos en la búsqueda de su libertad, este escenario dio pie a una interesante contradicción que Guido Barona plantea en su ensayo "Ausencia y presencia del 'negro' en la historia colombiana": el hecho de que las rebeliones, las sublevaciones y los palenques en lo que sería la Nueva Granada, no negaron la esclavitud a partir de un proyecto político y social, es decir, no pretendieron derrumbar las estructuras esclavistas. Más bien, fueron un mecanismo de inserción social de los cimarrones que legitimó la esclavitud. ${ }^{2}$

Existían dos tipos de fugas de esclavos: las de carácter temporal y las de carácter definitivo. En cuanto a las primeras, dice Anthony McFarlane, que no siempre tenían lugar con el objeto de lograr la libertad; lo que deseaban era conservar algunas prerrogativas, por ejemplo, que se les permitiese trabajar, estar adecuadamente vestidos y alimentados, tener alguna facilidad de movimiento y la posibilidad de participar en la economía de mercado. Huían en un intento por regular, mejorar o cambiar el trato que recibían dentro de la esclavitud. ${ }^{3}$

El segundo tipo estaba conformado por esclavos que, individualmente o en grupo, aspiraban a rebelarse escapando permanentemente hacia la libertad. Era una forma de resistencia contra el sistema esclavista, que aspiraba a una ruptura total con el cautiverio y expresaba la aspiración de conformar comunidades de vida autónoma.

En el Nuevo Mundo, en todos los espacios donde la esclavitud fue una institución fundamental, el temor a la revuelta y el problema de los fugitivos atribularon a los funcionarios y a los pobladores. Lejos de ser la sociedad colonial plácida y pacífica, estuvo acosada por la inestabilidad causada por la amenaza de reacción violenta de los esclavos. Ellos huían buscando la libertad, impulsados por las difíciles condiciones de vida que padecían en las estancias y las minas. La vivienda, el vestido y la alimentación eran precarios; la nutrición era pobremente balanceada e insuficiente. Además, sufrían

\footnotetext{
${ }^{1}$ Hermes Tovar Pinzón, De una chispa se forma una hoguera: Esclavitud, insubordinación y liberación (Tunja: Universidad Pedagógica y Tecnológica de Colombia, 1992), 13-26.

2 Guido Barona Becerra, “Ausencia y presencia del 'negro' en la historia colombiana," Memoria y sociedad 1, no. 1 (noviembre 1995): 104-5.

3 Anthony McFarlane, "Cimarrones y palenques en Colombia, siglo XVIII," Historia y espacio, no. 14 (junio 1991): 73-5.
} 
las consecuencias de una política de castigo y terror como medio de control. Cuando la brutalidad se unió a un trabajo arduo y en malas condiciones, los motivos para escapar aumentaron.

Comenta Anthony McFarlane que un grupo de cimarrones, pertenecientes a la Corona, argumentaba que había escapado porque el administrador les había despojado de sus días de fiesta, les había impedido cultivar sus productos agrícolas y no cumplía con la entrega de las raciones de carne y vestuario. ${ }^{4}$

En 1685, Juan Matamba, un esclavo negro de Felipe de Silva, vecino del valle de Ciénaga, declaró ante las autoridades que hacía quince días que estaba preso en la cárcel real de la Audiencia de Santafé, traído desde la ciudad de Tocaima, por Cristóbal de Velasco, ministro alguacil, por haberse ausentado del poder de su amo "por el mal trato que siempre me daba, trayéndome desnudo y muerto de hambre como lo tiene de costumbre, que ya no lo pude llevar y por esta ocasión me huí." El esclavo solicitó a la Audiencia ponerlo a pregones para ser vendido o ser entregado al depositario general. La Audiencia decidió que Juan Matamba fuera vendido en subasta pública por cimarrón. ${ }^{5}$

El anterior es un ejemplo concreto de por qué los esclavos presionados por las circunstancias deplorables de su estado buscaban escapar. Si bien la libertad era una condición deseable, los malos tratos, la alimentación insuficiente, el exceso de trabajo, los empujaban a convertirse en cimarrones.

Según Frederick P. Bowser, otra de las principales razones de la fuga era la separación de la familia o el cónyuge. Hombres y mujeres de color casados, pertenecientes a diferentes propietarios y separados por la exigencia de la esclavitud, intentaron reunirse escapando. En ocasiones eran los hijos los que huían buscando a sus padres. De cuando en vez, había propietarios bondadosos o inteligentes que terminaban tales separaciones adquiriendo al cónyuge. ${ }^{6}$

\footnotetext{
${ }^{4}$ Ibid., 73 .

${ }^{5}$ Archivo General de la Nación, Bogotá, Negros y esclavos de Bolívar, 9, fols. 959-68 (en adelante citado como AGN).

${ }^{6}$ Frederick P. Bowser, El esclavo africano en el Perú colonial, 1524-1650, Colección América nuestra, América colonizada, no. 4 (México, D.F.: Siglo XXI, 1977), 249.
} 
David M. Davidson concluye diciendo que: "la vida familiar y marital inestable, el mal trato, la sobrecarga de trabajo, y la escasez de canales efectivos para la libertad contribuyeron de manera poderosa al descontento. Aun cuando estas condiciones variaron ciertamente de una región, actividad económica y amo a otro, el peor trato y las revueltas más brutales ocurrieron en las minas y en las plantaciones de azúcar de la colonia." 7

Aunque la economía de plantación no se dio al norte del Nuevo Reino, las condiciones de vida de las estancias agrícolas y hatos de ganado no eran las mejores; lo mismo aconteció en las minas. Tampoco, los esclavos de servicio doméstico estuvieron exentos de las situaciones de castigo y maltrato por parte de los amos. Desde allí, huyeron muchos de ellos, uniéndose en los palenques a otros de la región.

Francisco Zuluaga quien trabaja el cimarronismo en el suroccidente del Virreinato de la Nueva Granada, en el siglo XVIII, dice que en aquél se hacen presentes la represión del amo, la resistencia y el sentido libertario del esclavo, la capacidad represiva o asimiladora del Estado y la habilidad de las comunidades negras para enfrentar un proceso de aculturación-deculturación y construir sociedades en las que valores ancestrales se conjugaron con los aprendidos o impuestos por la sociedad mestiza. ${ }^{8}$

De igual manera señala, en relación con lo que impulsaba a los esclavos a huir o a los libres negros a unirse con sus congéneres en el palenque, que en los casos en que el maltrato promovía la huida, éste se convertía en una justificación de la fuga pero no explica verdaderamente lo que los llevaba a escapar. Ofrece el ejemplo de los cimarrones de Los Cerritos, a orillas del Río Otún, quienes no lo hicieron por repulsión al maltrato sino por la posibilidad de enfrentar bélicamente al blanco o sencillamente como se decía en esa época, para enmontarse. Concluye que: "Esto demuestra cómo, en medio de múltiples razones particulares... existía un común denominador, la constitución de su propia sociedad.",

\footnotetext{
${ }^{7}$ David M. Davidson, "El control de los esclavos negros y su resistencia en el México colonial, 15191650," en Sociedades cimarronas: Comunidades esclavas rebeldes en las Américas, comp. Richard Price, Colección América nuestra, América colonizada, no. 33 (México, D.F.: Siglo XXI, 1981), 86.

${ }^{8}$ Francisco U. Zuluaga R., "Cimarronismo en el suroccidente del antiguo Virreinato de Santafé de Bogotá," en De ficciones y realidades: Perspectivas sobre literatura e historia colombianas, comp. Alvaro Pineda Botero y Raymond L. Williams (Bogotá: Tercer Mundo, 1989), 340.

${ }^{9}$ Ibid., 345-6.
} 


\section{Aproximaciones teóricas al tema}

Existen fundamentalmente dos grandes aproximaciones teóricas al tema de los cimarrones y la vida en los palenques. Algunos autores muestran rasgos de alguna de ellas, pero matizados por características de la otra. Sin embargo, teniendo en cuenta esta última circunstancia, merece la pena resaltar las peculiaridades de las dos posiciones fundamentales.

En Colombia, la postura teórica sobre las "huellas de africanía" estuvo liderada por la célebre antropóloga Nina S. de Friedemann. Para esta autora las huellas de africanía: "se entienden como símbolos, iconografías y asociaciones iconográficas que permaneciendo en el consciente y el subconsciente de los africanos y sus descendientes, han tomado parte en la formación de las culturas afroamericanas." 10 En este proceso, alude a la teoría de Gregory Bateson sobre el aprendizaje y los mecanismos de comunicación de una cultura. Sus manifestaciones aparecen en los palenques, los cabildos y las juntas de brujería de la época colonial y en los carnavales, en el habla, en los cantos y bailes de muertos, en la organización social y en la religión de los descendientes de antiguos africanos. En el campo de las relaciones sociales, se aprecia que la ética y los rasgos estructurales de la familia extensa africana están presentes en las formas familiares de Afroamérica. En el pensamiento religioso, los rituales son ricos en expresiones con memorias de africanía en sus imaginarios y cosmovisiones. ${ }^{11}$

Agrega la doctora Friedemann que el concepto de huellas de africanía está ligado al de la reintegración étnica que permite señalar el reencuentro cultural de los africanos, después de su desarraigo de la tierra nativa, durante la trata en Africa y posteriormente, en América. Esta teoría rectifica la tesis sobre la dispersión étnica y la ruptura cultural de los africanos llegados como esclavos al Nuevo Mundo. ${ }^{12}$

Según esta antropóloga, nuevos autores africanistas sustentan en su debate una oposición al modelo de criollización propuesto por Sidney Mintz y Richard Price, los autores que lideran la propuesta antagónica. A propósito del concepto de criollización, retoma del escritor Lovejoy que: "es eurocéntrico el enfatizar que la cultura africana se

\footnotetext{
${ }^{10}$ Nina S. de Friedemann, "Historiografía afroamericana del Caribe: hechos y ficciones," América negra, no. 7 (junio 1994): 12.

${ }^{11}$ Nina S. de Friedemann, "Vida y muerte en el Caribe afrocolombiano: Cielo, tierra, cantos y tambores," América negra, no. 8 (diciembre 1994): 85.

${ }^{12}$ Friedemann, "Historiografía afroamericana del Caribe," 12-3.
} 
sumergió y se amalgamó bajo la esclavitud en un molde americano que reforzó el dominio de la gente de origen europeo."13

Guido Barona pone en tela de juicio las ideas de Nina de Friedemann y de Norman Whiten en relación con el significado de las rebeliones y los procesos de resistencia de los esclavos durante el período colonial a los que estos autores quieren adjudicar un sentido de la búsqueda de la libertad a partir de su determinación de clase. Consideran que los esclavos en el período colonial, ya conformaban grupos étnicos y produjeron formas de organización que los diferenciaron de los otros sectores socioculturales. De esta manera, afirma Guido Barona, se produce una ficción sobre las rebeliones, con "un matiz de identidad cultural a partir del cual se produjo la lucha por la libertad."14

Los procesos de huida individual y colectiva basados en la unidad cultural del hombre negro son expresiones que reducen la realidad histórica. Un obstáculo a esta forma de interpretar la historia de la esclavitud, en el territorio de la Nueva Granada, lo constituye la diversidad de las procedencias africanas y de los esclavos criollos en los enclaves mineros. $^{15}$

La teoría de la criollización tuvo sus antecedentes en las ideas del famoso antropólogo e historiador mexicano Gonzalo Aguirre Beltrán quien realizó un estudio pionero, profundo y serio, sobre el origen de la esclavitud negra en el virreinato de Nueva España. También, abrió el camino para el análisis de los palenques. Este autor afirma que:

El negro, ciertamente, no pudo reconstruir en la Nueva España las viejas culturas africanas de que procedía. Su status de esclavo, sujeto a la compulsión de los amos esclavistas cristianos, le impidió hacerlo; aun en aquellos casos frecuentes en que la rebelión lo llevó a la condición de negro cimarrón y, aislado en los palenques, vivió una vida de absoluta libertad, su contacto con el indígena y con el mestizo aculturado le impidió llevar a cabo esa reedificación... el negro sólo pudo, en los casos en que alcanzó un mayor aislamiento, conservar algunos rasgos y complejos culturales africanos... ${ }^{16}$

\footnotetext{
${ }^{13}$ Nina S. de Friedemann, "Diálogos atlánticos: experiencias de investigación y reflexiones teóricas," América negra, no. 14 (diciembre 1997): 174-5.

${ }^{14}$ Barona, "Ausencia y presencia del 'negro,", 97.

${ }^{15}$ Ibid., 102.

${ }^{16}$ Gonzalo Aguirre Beltrán, Cuijla: Esbozo etnográfico de un pueblo negro (México, D.F.: Fondo de Cultura Económica, 1958), 10.
} 
Por su parte, Germán de Granda afirma que si bien es un aspecto fundamental constatar las retenciones de elementos o rasgos culturales africanos en los núcleos de cimarrones, los patrones culturales africanos se vieron sometidos, en el nuevo hábitat americano, a la acción de varios factores que afectaron con profundidad y extensión diversa, las normas de comportamiento de los grupos étnicos traídos como esclavos. De allí, que sea preciso tener en cuenta dos aspectos importantes. El primero de ellos se deriva de la adaptación de los grupos africanos a las nuevas situaciones sociales, económicas y ecológicas que encontraron en América y de la posterior reinterpretación de sus patrones culturales, modificados y adaptados dentro de la estructura total de la sociedad. El segundo está relacionado con la sustitución de los elementos culturales africanos por los homólogos euroamericanos. Los resultados de este proceso de transculturación en los grupos étnicos de origen africano fueron de diferente extensión, según las diversas áreas geográficas americanas. $^{17}$

Entre los autores que con más precisión defienden la teoría de la criollización se encuentra Richard Price, quien ha realizado estudios sobre los negros de la selva de Surinam. En cuanto a las ideas culturales y los modelos sociales que los cimarrones trajeron consigo a los palenques, Price considera que es esencial destacar la diversidad de valores y puntos de vista que estuvo presente en la mayoría de los grupos cimarrones originales. Las filiaciones tribales africanas eran diversas y la gama de adaptaciones a la esclavitud fue muy amplia. El cimarronaje no fue un fenómeno homogéneo desde el punto de vista del origen y de las formas de pensamiento de los esclavos. El significado del cimarronaje fue distinto para ellos de acuerdo con sus diferentes posiciones sociales, lo que a su vez estuvo influido por factores diversos como su lugar de nacimiento, el tiempo de permanencia en el Nuevo Mundo, las tareas y actividades desempeñadas como esclavos y el trato recibido de sus amos o capataces, así como por otras consideraciones como la proporción entre negros y blancos en la región, la relación numérica entre esclavos y negros libres, las oportunidades de manumisión, etc. ${ }^{18}$

El equipo cultural que portaron los cimarrones a los palenques fue bastante diverso; incluyó contribuciones de los africanos que representaron variedad de lenguajes y culturas, también de los criollos y de los africanos que llevaban tiempo en América.

\footnotetext{
${ }^{17}$ Germán de Granda, "Cimarronismo, palenques y hablas criollas en Hispanoamérica," Thesaurus: Boletín del Instituto Caro y Cuervo 25, no. 3 (1970): 448-50.

${ }^{18}$ Price, introducción a Sociedades cimarronas, 33.
} 
Todo ello implicaba una gama de ajustes diversos a la esclavitud y diferentes modos de enfrentar los problemas y orientaciones con la realidad.

Si bien, los cimarrones acudieron a su herencia africana al construir sus culturas en los palenques y buscaron en ella principios organizativos diversos, la formación de grupos de cimarrones, con todo tipo de culturas, sólo fue posible por la existencia previa de culturas esclavas ya maduras combinadas con un compromiso ideológico compartido con las cosas de Africa. Los afroamericanos en el Nuevo Mundo desarrollaron modos característicos afroamericanos de conducta, desde el comienzo. ${ }^{19}$

Más claramente, explica Richard Price:

Aunque sea 'africano' en el carácter, no se puede ubicar dentro de un origen tribal específico a ningún sistema cimarrón de carácter social, político, religioso o estético de manera confiable. Más bien muestran su composición sincretista, forjada en el encuentro temprano de gentes portadoras de diversas culturas africanas, europeas y amerindias, dentro del asentamiento dinámico del Nuevo Mundo. ${ }^{20}$

En cuanto a las rebeliones de los cimarrones en Jamaica, Orlando Patterson afirma que el área de Africa occidental, de donde procedía la mayoría de los esclavos que entraron en esta isla, se caracterizaba por su diversidad tribal y cultural. Las dos terceras partes de los esclavos arribados a Jamaica provenían de Ghana y Nigeria. Si bien, diversos elementos de las culturas del Africa occidental sobrevivieron al proceso de esclavitud, hubo una desintegración general de las culturas de los africanos importados. Las creencias, los valores, las ideas se destruyeron rápidamente bajo el impacto de la esclavitud. $^{21}$

En relación con los quilombos brasileños, Stuart B. Schwartz propone que las comunidades de fugitivos desarrollaron tradiciones sincréticas que amalgamaron elementos brasileños y africanos. Sus habitantes parecían haber sido de orígenes diversos, criollos de Brasil y africanos de diferentes orígenes étnicos. Por mucho tiempo, se creyó que el quilombo de Palmares basó su organización política y social en un número de formas tradicionales africanas, sin embargo, hoy, se reconoce que como la

\footnotetext{
${ }^{19}$ Ibid., 35-6, 38 .

${ }^{20}$ Ibid., 38.

${ }^{21}$ Orlando Patterson, "Esclavitud y revueltas esclavas: Análisis sociohistórico de la primera guerra cimarrona, 1665-1740," en Sociedades cimarronas, 191.
} 
mayoría de las comunidades de fugitivos combinó estos aspectos con influencias culturales europeas y adaptaciones locales específicas. Palmares parece haber sido una adaptación de formas culturales africanas a la situación colonial brasileña en la que esclavos de variados orígenes, africanos y criollos se unieron en su común oposición a la esclavitud. $^{22}$

Las ideas de McFarlane dan a entender su proximidad con la teoría de la criollización cuando habla de la organización política y social de los cimarrones en los palenques del siglo XVIII y dice que crearon un sistema político, informal y autónomo a imitación del gobierno hispánico. Asimismo, cuando se refiere al aspecto religioso en el que absorbieron los elementos prevalecientes de la cultura hispánica. Esto demostraría cómo los esclavos adaptaron las prácticas de la cultura dominante a sus propias necesidades y como dice textualmente "refleja la existencia de una cultura esclava criolla o americana, cultura que se había desarrollado más allá de la herencia africana." 23

Este autor, además de apoyar la teoría de la criollización plantea la tensión entre libertad y esclavitud al exponer cómo aún dentro de la esclavitud, muchos cautivos negros no pensaron en la fuga definitiva para conseguir la libertad sino que prefirieron usarla como táctica de protesta: "las fugas de esclavos no siempre se llevaban a cabo con miras a lograr la libertad." Más bien, lo que deseaban era conservar cierto tipo de libertad dentro de la esclavitud: trabajar sin ser maltratados, estar vestidos y alimentados suficientemente, gozar de alguna libertad de movimiento y de participación en la economía de mercado. Su propósito no era desafiar al sistema esclavista sino proteger la posición de los esclavos dentro de éste por medio de privilegios prácticos. ${ }^{24}$ Esto explicaría por qué el cimarronaje definitivo no fue un objetivo tan generalizado y cómo los esclavos criollos, principalmente, aprendieron a convivir con el sistema y prefirieron optar por la legislación paternalista para conseguir la libertad. Como afirma Hermes Tovar: la vida de los esclavos negros osciló "entre el radicalismo de huir a un palenque y la resignación de servir." 25

\section{Levantamiento de esclavos al norte del Nuevo Reino}

\footnotetext{
${ }^{22}$ Stuart B. Schwartz, "Rethinking Palmares: Slave Resistance in Colonial Brazil," en Slaves, Peasants, and Rebels (Urbana y Chicago: University of Illinois Press, 1996), 117, 122, 124.

${ }^{23}$ McFarlane, "Cimarrones y palenques," 69-70.

${ }^{24}$ Ibid., 75-6.

${ }^{25}$ Tovar, De una chispa, 58.
} 
Uno de los primeros levantamientos de esclavos negros de los que se tiene evidencia a través de los cronistas fue el acontecido en la Provincia de Santa Marta. Se dice que cinco años después de la fundación de la ciudad (en 1530), fue destruida como resultado de una rebelión de esclavos. Reconstruida en 1531, sufrió los efectos de una nueva rebelión en 1550. Algunos científicos sociales como Reichel Dolmatoff ven en la formación del palenque de La Ramada una consecuencia de este incidente. Sin embargo, Dolcey Romero considera que a pesar de que algunos historiadores hablan de La Ramada como una región, a partir de allí se oficializó la existencia de este palenque. ${ }^{26}$

A finales del siglo XVI, las rancherías de minas de Zaragoza, en la Provincia de Antioquia concentraban una gran cantidad de esclavos negros dedicados a la extracción del oro. Las condiciones orográficas, montes de vegetación tupida cercanos a las minas, atraían a la población esclava de las rancherías y la invitaban a la rebelión y a la fuga.

El cronista Antonio Vázquez de Espinosa en su Compendio y descripción de las Indias Occidentales, informa sobre la gran rebelión de esclavos que tuvo lugar en las minas de Zaragoza. Aunque fue finalmente dominada por las tropas reales después de un año de intentos, el cronista dice que en 1598 muchos esclavos se alzaron, desampararon las minas, mataron a los mineros, a algunos de sus amos y se fortificaron en palenques. En esta alteración del orden, se le encomendó la reducción de los esclavos al capitán general Juan Meléndez de Valdés quien después de muchas circunstancias y luchas desbarató el palenque e hizo justicia con los cimarrones que aprehendió. ${ }^{27}$

En el año de 1607, en la ciudad de Nuestra Señora de los Remedios ocurrió un levantamiento que estuvo a punto de trastocar la situación socioeconómica de una de las zonas más importantes de producción de metales de aquella época. Desde Cartagena habían sido llevados numerosos esclavos para el trabajo de las minas de oro. Según el cronista fray Pedro Simón, en 1596, había en dicha ciudad unos dos mil repartidos entre veinte españoles. Esta cantidad disminuyó en los años siguientes pero es de presumir que para 1607, cuando se produjo el alzamiento, todavía era considerable.

La gravedad del levantamiento de Remedios estribaba en tres hechos fundamentales: la paralización de la producción minera, el peligro de que el ejemplo fuera seguido en otras

\footnotetext{
${ }^{26}$ Dolcey Romero Jaramillo, “Cimarronaje y palenques en la Provincia de Santa Marta," Huellas, no. 42 (diciembre 1994): 35.

${ }^{27}$ Antonio Vázquez de Espinosa, Compendio y descripción de las Indias Occidentales, Smithsonian Miscellaneous Collections, no. 108 (Washington, D.C.: Smithsonian Institution, 1948), 321.
} 
partes y los graves trastornos que producía en las vías de comunicación. Los esclavos estaban favorecidos por la vegetación espesa de la región que los amparaba e impedía su persecución.

El presidente de la Audiencia de Santafé informó al Rey, en comunicación del 20 de junio de 1608, sobre el levantamiento de Remedios, diciendo que los negros se habían alzado y huido a las montañas desde donde convocaban a otros para que hicieran lo mismo. Habían formado una tropa que atacaba los caminos reales, causando perjuicios en el comercio y en la labor de las minas. ${ }^{28}$

Según Aquiles Escalante, el más vigoroso movimiento en la costa del Caribe colombiano aconteció en la Gobernación de Cartagena, a comienzos del siglo XVII, siendo gobernador don Jerónimo de Suazo Casasola. Domingo Biohó, al frente de treinta hombres y mujeres, se escapó al arcabuco de la Ciénaga de la Matuna. Las arremetidas de Domingo Biohó y los cimarrones que lo seguían estremecieron la cotidianidad de Cartagena, Tolú, Mompox y Tenerife, con sus asaltos y robos a las estancias, hatos y sementeras. ${ }^{29}$

En ese espacio, al sur de la villa de Tolú, estableció un poblado y lo rodeó con palizadas, constituyendo el palenque de la Matuna. Hacia este paraje salieron, en su búsqueda, los propietarios, varios militares y soldados, quienes fueron atacados furiosamente por los cimarrones y obligados a regresar a la ciudad de Cartagena. Los siguientes gobernadores de la provincia, temerosos de que la revuelta tomase fuerza porque Domingo Biohó se había constituido en "rey de la Matuna," enviaron nuevas milicias y lo que encontraron fue un poblado fortificado en medio de ciénagas y caños que, unidos a la fragosidad de la montaña, les hacía imposible destruirlo.

Aunque en nuevas incursiones las tropas lograron matar y prender a varios cimarrones, el palenque seguía en pie. Fue por eso que las autoridades decidieron concertar pacíficamente con los cimarrones. Se habló de una tregua en la que Domingo Biohó se obligaba a dejar la guerra a condición de que el gobernador, a nombre del Rey, perdonase la vida de los cimarrones. El gobernador, considerando que la seguridad de los españoles y su hacienda eran más importantes, resolvió concederles la paz.

\footnotetext{
${ }^{28}$ Manuel Lucena Salmoral, "Levantamiento de esclavos en Remedios," Boletín cultural y bibliográfico 5, no. 9 (septiembre 1962): 1127-8.

${ }^{29}$ Aquiles Escalante Polo, El negro en Colombia, Monografías sociológicas, no. 18 (Bogotá: Universidad Nacional de Colombia, 1964), 114.
} 
Sin embargo, este breve tratado de paz no llegó a buen término. Los cimarrones viendo que su propuesta no había tenido efecto comenzaron a irritarse y a hacer nuevos asaltos, con respuestas violentas de las autoridades.

En 1613, el gobernador Diego Fernández de Velasco consideró devastadoras para el fisco las expediciones militares y decidió cambiar de política. Se dio a la tarea de reducirlos pacíficamente y se les concedieron algunas prerrogativas: los cimarrones de la Matuna consiguieron licencia para entrar y salir de la ciudad de Cartagena con su capitán Domingo Biohó; a Biohó se le permitió vestir a la española. Dice fray Pedro Simón que éste "andaba con tanta arrogancia que demás de andar bien vestido a la española, con espada y daga dorada, trataba su persona como un gran caballero." 30

El gobernador García Girón, en 1621, acosado por las presiones de los vecinos de Cartagena y deseoso de acabar con el alzamiento decidió cambiar de política. Argumentaba que los dueños de estancias temerosos de sus acciones "le reconocían y regalaban" y al palenque de la Matuna iban a parar todos los esclavos que se fugaban de la provincia. En un confuso incidente con la guardia de la ciudad, Domingo Biohó fue tomado preso y llevado ante el gobernador que lo hizo ahorcar "con lo cual han quedado todos los negros muy quietos y pacíficos." 31

Fue así como por más de dos décadas, en medio de guerras y treguas, el palenque de la Matuna logró mantenerse como un refugio en donde los esclavos pudieron escapar hacia la libertad.

Los males causados por la situación social seguían vigentes; los cimarrones continuaban atacando las estancias y causando daños y robos a los vecinos y sus propiedades. En 1631, ya se tenían indicios de la existencia de un palenque en la otra banda del Río Magdalena y otros en las Serranías de María. Hacia finales del siglo XVII, las circunstancias con los cimarrones se hacían cada vez más graves para los gobernadores de las provincias. Para ese entonces, había palenques en la Provincia de Santa Marta, en la margen derecha del río Magdalena y en tres puntos claves de la Provincia de Cartagena: los del norte conocidos con los nombres de Betancur y Matudere o el

\footnotetext{
${ }^{30}$ Fray Pedro Simón, Noticias historiales de las conquistas de tierra firme en las Indias Occidentales (Bogotá: Biblioteca de Autores Colombianos, 1953), 6:173.

${ }^{31}$ Angel Valtierra S.J., Pedro Claver: El Santo redentor de los negros (Bogotá: Banco de la República, 1980), 1:460.
} 
Tabacal, ubicados en las Sierras de Luruaco; los del centro eran San Miguel y el Arenal, los más estables y permanentes, situados en las Sierras de María. Allí mismo estaban el de Duanga, María Angola, Joyanca, Sanagual, Manuel Embuyla, María Embuyla y Arroyo Piñuela, surgidos contemporáneamente o a raíz de la destrucción de otros; los del sur, estaban localizados en la Serranía de San Lucas, conocidos con los nombres de Cimarrón y Norosí.

Las sierras de Luruaco y las de María, de baja altura, favorecieron el asentamiento de cimarrones por lo tupido del terreno y las dificultades de penetración. La Serranía de San Lucas, entre los ríos Nechí y Magdalena, fue otro reducto de cimarrones que estuvo favorecido por las arenas auríferas que arrastraban los ríos y quebradas. Éstas sirvieron como fuente de ingreso para intercambios y trueques de los apalencados con las estancias de los alrededores. ${ }^{32}$

En 1655, el gobernador de Cartagena, don Pedro Zapata, decidió emprender una arremetida contra un palenque que los negros fugitivos de Cartagena habían construido cincuenta años antes en la otra banda del río de la Magdalena. Este ataque suscitó conflictos jurisdiccionales debido a que el palenque estaba situado en la gobernación de Santa Marta, fuera de su dominio. ${ }^{33}$

Con el pasar de los años se fue creando un estado de alerta en Cartagena por el temor a que hubiese una conjuración entre los esclavos de la provincia y los de los palenques. Por su parte, las autoridades veían en los cimarrones a posibles aliados de los enemigos extranjeros que intentaran atacar al puerto. Pero sobre todo, lo que servía de estímulo a los cimarrones de la Provincia de Cartagena era el ejemplo de los de Santa Marta. Parece que un buen número de ellos, establecidos entre Riohacha y Santa Marta habían pedido al gobernador que los declarase libres y les concediese tierras para su poblamiento; lo cual les fue concedido en 1679, con la suposición de que ayudasen en la defensa y atemorizasen a los indios de guerra. ${ }^{34}$

En 1682, el capitán general de Cartagena decidió emplear la táctica de "mano dura" y envió a Bartolomé Narváez a destruir los palenques situados en las Sierras de María. El intento fue fallido puesto que la tropa española era insuficiente para el ataque. La

\footnotetext{
${ }^{32}$ María del Carmen Borrego Plá, Palenques de negros en Cartagena de Indias a fines del siglo XVII (Sevilla: Escuela de Estudios Hispano-americanos, 1973), 9.

${ }^{33}$ Roberto Arrázola, Palenque primer pueblo libre de América (Bogotá: Todo Impresores, 1986), 58.

${ }^{34}$ Borrego, Palenques de negros, 30.
} 
situación continuó siendo difícil por varios años porque los cimarrones hostigaban a los esclavos de las estancias, asesinaban a los viandantes y al huir se llevaban los aperos para utilizarlos en sus sementeras.

Después de varios intentos de destrucción por parte de las autoridades civiles y militares, el gobernador Juan Pando de Estrada recibió, en 1686, noticias de que los criollos de los palenques proponían que se les diese la libertad y tierras para su sustento y, a cambio, se dispondrían a hacer la paz.

En mayo de 1688, se expidió una real cédula que insistía en perseguir el rastro de los cimarrones hasta acabar con ellos y los caudillos de los palenques debían ser severamente castigados.

A través del padre Baltasar de la Fuente, cura doctrinero del pueblo de Turbaco, el capitán de los palenques de las Sierras de María, Domingo Criollo, hizo saber al gobernador que estaban dispuestos a una tregua y a obedecer a la autoridad provincial, bajo ciertas condiciones: que el gobernador diese libertad a los cimarrones que le presentasen obediencia, que se les señalase un territorio para poblar y tener sus tierras de labranza. Y que a dicha población se le pusiese un cura y un justicia mayor españoles. En contraprestación, se obligaban a perseguir a los esclavos de la provincia que huyesen a partir de ese momento.

En 1691, el Real Consejo de las Indias expidió una cédula en la que ordenaba al gobernador de Cartagena que anulase la cédula de 1688 y no volviese a usarla, gracias a que los cimarrones querían sujetarse, según ciertas condiciones fáciles de llevar a cabo, sin necesidad de tener que usar la fuerza de las armas.

Paralelamente se extendió por la ciudad la idea de que se estaba organizando una conjuración entre los esclavos domésticos y los cimarrones. El cabildo se manifestó contrario a la aplicación de la cédula; el clamor del pueblo se enardeció de tal forma que los vecinos se reunieron en cabildos pidiendo al gobernador que tomase las armas contra los cimarrones de las Sierras de María y demás palenques de la provincia. De esta forma, el gobernador consideró formalmente la posibilidad de atacar a los palenques y buscar su destrucción. Se empezaría por el Tabacal porque sus pobladores eran los que cometían más desafueros; después se procedería contra los otros. Los costos de la guerra serían sufragados por los vecinos. 
Durante varios años de la década de 1690, se desarrollaron las más cruentas luchas. Gran cantidad de fugitivos fueron sacrificados y otros tantos, enviados a Cartagena para su entrega a los propietarios, o la venta y embarque para otros reinos. La mayoría de los palenques fue destruida y los pobladores que quedaron se diseminaron por los montes en busca de otros refugios.

Mientras todo este proceso tenía lugar, las autoridades demostraron su incapacidad para lidiar con el problema pacíficamente. Cuando la situación se tornaba insoportable ofrecían conceder prerrogativas y se disponían a treguas y tratados de paz, pero la inconsistencia de las autoridades coloniales, los titubeos de las metropolitanas y las presiones de los vecinos, lideradas por los miembros del cabildo, no permitieron que llegaran a un entendimiento que concluyera en una paz definitiva.

Ligado al desarrollo de estos acontecimientos tuvo lugar la formación del más famoso palenque de la historia colombiana, el palenque de San Basilio. De éste sólo se tiene evidencia histórica a partir del siglo XVIII, cuando, gracias a la acción de quien gobernaba el obispado de Cartagena, el ilustrísimo don Antonio María Casiani (17131717), miembro de la congregación de San Basilio, el palenque fue sometido y pacificado.

Explicar con certeza el origen histórico del palenque de San Basilio ofrece confusiones. A primera vista podría pensarse en relación con el palenque de la Matuna de Domingo Biohó, pero según los documentos para la historia de Cartagena recogidos por José P. Urueta:

San Basilio, población de negros en lo interior del monte, tuvo su origen de muchos esclavos fugitivos de varias personas de esta ciudad [Cartagena], que abrigados de la asperosidad de la montaña de María, entre su ciénaga y su sitio de Mahates establecieron su palenque. No se pudieron reducir a servidumbre aunque se entró varias veces con fuerza de armas, en que se derramó mucha sangre, hasta que al principio de este siglo [XVIII], gobernando el obispado el ilustrísimo Sr. don Antonio María Casiani, los redujo con acuerdo del señor gobernador de la provincia a esta población con perdón general y goce de libertades, y la precisa obligación de que no pudiesen admitir allí otros esclavos prófugos en lo futuro... ${ }^{35}$

\footnotetext{
${ }^{35}$ Aquiles Escalante Polo, "Notas sobre el palenque de San Basilio, una comunidad negra en Colombia," Divulgaciones etnológicas 3 (1954): 229-30.
} 
Del anterior documento se deduce, a manera de hipótesis, que si bien a finales del siglo XVII, los palenques de las Sierras de María se consideraron destruidos, es muy probable que muchos de los cimarrones esparcidos lograron concentrarse de nuevo y se restablecieron hasta el momento en que fueron reducidos con la intermediación del obispo Casiani y pactaron un tratado de paz con las autoridades, logrando el reconocimiento definitivo de su población.

Es casi un hecho comprobado (del que se dará cuenta en un próximo estudio) que el palenque de San Miguel, uno de los más estables de las Sierras de María, sería el que dio origen a la población de San Basilio. La "nueva" población tomó este nombre de la orden religiosa a la que pertenecía el obispo Casiani, y la iglesia fue dedicada a la advocación del arcángel San Miguel, nombre que de años atrás llevaba el palenque. De esta manera se legitimaba cristianamente el poblado y sus habitantes se convertían en súbditos de la corona española.

\section{Los cimarrones y la Santa Hermandad}

A finales del siglo XVI y en la primera mitad del siglo XVII, la Santa Hermandad jugó un papel significativo en la aprehensión de los cimarrones. Frederick Bowser es explícito en el carácter que tuvo en el Virreinato del Perú.

En 1557, el virrey Cañete estableció el cargo de alcalde de la Hermandad, ocupado por dos alcaldes ordinarios salientes que automáticamente se convertían en alcaldes de la Hermandad por el siguiente año. Tenían las mismas tareas en las áreas rurales que las de los alcaldes ordinarios en las poblaciones. Debido al gran número de esclavos que había en Lima dedicaron mucho tiempo a la captura de los fugitivos. Bajo el mando de ese cuerpo estaba un número variable de ayudantes, llamados cuadrilleros, a quienes correspondía patrullar el campo.

En el apogeo de sus funciones, la Hermandad fue una institución económica y eficiente, capaz de reducir el número de cimarrones y de organizar expediciones especiales cuando era menester enfrentarlos. La Hermandad dependía de un sistema de financiamiento constituido por un impuesto representado en una tasa cobrada por cabeza de los bozales que entraban al Callao.

Después de un período de suspensión, en 1620, estaba vigente el cargo de alcalde de la Santa Hermandad y fue puesto bajo el control de la Corona. En 1633, se puso en venta el 
cargo en beneficio de la caja real. La transformación de la Hermandad en una organización dominada por un funcionario propietario coincidió con un marcado aumento de la actividad cimarrona en los alrededores de la ciudad de Lima. ${ }^{36}$

Infortunadamente, las fuentes primarias no ofrecen una información tan precisa y explícita de la importancia de la Santa Hermandad para la Provincia de Cartagena, en donde el problema cimarrón fue determinante durante todo el siglo XVII; sin embargo, datos aislados dan fe de la intervención de los alcaldes de la Hermandad en la persecución de los fugitivos, especialmente a finales del siglo XVI y en la primera mitad del siguiente.

Según carta del gobernador de Cartagena, don García de Girón, en el alzamiento provocado por Domingo Biohó en 1599, el rey de la Matuna nunca permitió que ningún español entrase con armas en el poblado y "a dos alcaldes de la hermandad que acaso fueron por allí a correr la tierra los desarmó diciendo que en su jurisdicción no habían de entrar gente armada." 37

Coincidiendo con Bowser, en cuanto a las actividades desempeñadas por los alcaldes de la Hermandad en el Perú, una de sus responsabilidades en la Provincia de Cartagena era recorrer el área rural con la intención de buscar y aprehender cimarrones.

Fray Pedro Simón, en su relato sobre la huida de treinta negros y negras bajo el mando de Domingo Biohó, también destaca la intervención del alcalde de la Hermandad, Diego de Torres quien salió a perseguirlos en compañía de Juan Gómez, propietario de Biohó, quien hacía las veces de cuadrillero, además de cuatro soldados, tres indios del pueblo de Bahayre y un flechero negro, que formaban un grupo de veinte soldados. Al llegar esta milicia al sitio donde se hallaban los cimarrones fue embestida por éstos, muriendo Juan Gómez y varios de los acompañantes.

El gobernador deseoso de acabar con el problema de los cimarrones que cada día se acrecentaba porque escapaban más esclavos, envió una nueva tropa dirigida por Diego Hernández Calvo, alcalde de la Hermandad constituida por veinticuatro soldados de los vecinos apertrechados de armas y municiones. El resultado de esta fuerza tampoco fue

\footnotetext{
${ }^{36}$ Bowser, El esclavo africano, 255-73.

${ }^{37}$ Valtierra, Pedro Claver, 1:459-60.
} 
exitoso y los daños, robos y asaltos de los cimarrones diezmaban las estancias, hatos y sementeras. ${ }^{38}$

La presencia de la Santa Hermandad era sin duda de gran importancia en la Provincia de Cartagena y su autoridad, tangible y contundente. En 1645, el capitán Francisco de Atienza, vecino de la villa de Tolú, por medio de su representante, se presentó ante la Audiencia de Santafé para apelar contra el agravio causado por el capitán Alonso Cuadrado Cid, provincial de la Santa Hermandad de Cartagena, por haberle condenado sin nombramiento de defensor a tres esclavos de su propiedad llamados: Francisco Criollo, Juan y Antonio Angola. Los esclavos fueron recluidos en la cárcel de Cartagena. El provincial de la Hermandad los había condenado a la pena de doscientos azotes, cada uno, y a servir un año en las fortificaciones, por haber huido de la estancia en donde trabajaban.

Según el representante de la defensa, estos esclavos nunca habían huido, hurtado cosa alguna, asistido a palenques ni se habían juntado con otros cimarrones. Argumentaba que además de ser nula la sentencia del provincial de la Santa Hermandad, se excedió notablemente en las penas sin tener en cuenta que sólo se castigaba a los cimarrones de acuerdo con la calidad del delito y con los daños causados. Solicitó la entrega de los esclavos, el pago de los jornales que hubiesen podido ganar durante el tiempo que habían permanecido en la fortificaciones y que el provincial fuese condenado a pagar los costos de la causa por la inequidad de la sentencia. ${ }^{39}$

La Santa Hermandad entró en conflictos de jurisdicción con otras instancias de gobierno y de justicia, compitiendo con ellas e intentando ejercer el control sobre algunos aspectos que consideraba propios. Uno de ellos fue el relacionado con asuntos pertinentes a los cimarrones, su persecución y ajusticiamiento. Al parecer los alcaldes de la hermandad consideraban que los alcaldes ordinarios interferían en sus funciones y no les permitían ejercer con propiedad sus responsabilidades, de allí que en ocasiones tuvieran que acudir ante la gobernación provincial o ante la Audiencia Real de Santafé para hacer valer sus derechos.

Fue así como el capitán Diego de Mesa, provincial de la Hermandad de la ciudad de Cartagena entabló un pleito contra las justicias ordinarias de esa ciudad por causa de

\footnotetext{
${ }^{38}$ Simón, Noticias historiales, 165-8.

${ }^{39}$ AGN, Negros y esclavos de Bolívar, 9, fols. 894-933.
} 
unos cimarrones que fueron aprehendidos por los cuadrilleros. El capitán Mesa argumentaba que la causa le correspondía por tratarse de asuntos en los que la hermandad actuaba y por ser él quien los había aprehendido con su gente. Además, había despachado mandamiento mucho antes que cualquier otra autoridad. En consonancia con su actuación, los cimarrones fueron conducidos a la estancia y ranchería de Diego de Mesa.

En este estado de cosas, se entrometieron a actuar y a conocer del caso los alcaldes ordinarios Francisco de Villa Castañeda y Cristóbal de Bustamente. El capitán Diego de Mesa los exhortó para que abandonaran sus pretensiones pero Cristóbal de Bustamante insistió en su empeño y dio cuenta del caso al gobernador de la provincia quien despachó comisión para que reconociesen la causa. ${ }^{40}$

\section{Vida en los palenques}

Son pocas las fuentes primarias que dan cuenta de las condiciones de vida de los cimarrones en los palenques. La escasa información se halla esparcida a lo largo de documentos cuya intención no es precisamente relatar cómo vivían y se organizaban los negros apalencados sino dar testimonio de la legitimidad de los propietarios. Este es el caso de los documentos de la Inquisición a cuyo tribunal eran conducidos los cimarrones apresados en los palenques para declarar su pertenencia. Esta situación se presentó cuando el Santo Oficio reclamaba la propiedad de algunos cimarrones aprehendidos en los palenques descendientes de antiguos esclavos fugitivos.

A pesar de la reducida información se tiene conocimiento de que los palenques tenían una economía basada en la horticultura. Cada cimarrón tenía su siembra de fríjol, una variedad de papa y plátanos; trabajaba el trozo de tierra que le correspondía y el producto de las cosechas era para su familia. Había también sementeras de yuca y maíz. Hacían sus casas, especie de chozas, de madera, caña, palma y bejuco que encontraban en los montes. El sistema defensivo de casi todos los palenques dependía de su propia localización estratégica en montes espesos y en la construcción de fosos cubiertos con puyas y latas; asimismo, se defendían usando arcos y flechas y, en ocasiones con armas de fuego. Mantenían contacto con los habitantes de las poblaciones vecinas y las estancias de la región con las que establecían intercambio de productos. ${ }^{41}$

\footnotetext{
${ }^{40}$ AGN, Negros y esclavos de Bolívar, 14, fols. 741-77.

${ }^{41}$ Arrázola, Palenque, 77; Borrego, Palenques de negros, 27,83,86.
} 
A finales del siglo XVI y en el XVII, en consonancia con lo que dice Richard Price, los caudillos de los palenques fueron africanos de origen. Durante este primer período se apeló a modelos de monarquía; las comunidades de cimarrones de esta época parecen haber diferido de aquellas formadas posteriormente, tanto en los tipos de hombres que seleccionaban como dirigentes como en los modelos utilizados para legitimar su autoridad. $^{42}$ El caso de Domingo Biohó es un buen ejemplo; se hacía llamar rey del arcabuco o rey de la Matuna, apelando a la monarquía como símbolo de autoridad.

Posteriormente, según Price en el siglo XVIII, los dirigentes cimarrones raras veces afirmaron ser africanos, la mayoría fue criolla y tendía a denominarse: capitanes, gobernadores, coroneles, en lugar de reyes. ${ }^{43}$ En Cartagena, este fenómeno se dio en la década de 1680, cuando Domingo Criollo era el capitán de los palenques de las Sierras de María y de la Magdalena.

La vida en los palenques era muy difícil pues siempre estaban en pie de guerra, preparados para defenderse contra las incursiones de las milicias españolas, de allí que sus formas de organización dependiesen de este aspecto, en gran medida. Se temía que los grupos familiares y de compañeros se destruyesen cuando los militares arremetieran. Por eso, una manera para consolidar la estabilidad familiar era que los cimarrones se agrupasen bajo la idea de pertenencia a un mismo amo; éste era, de acuerdo a la legislación, el propietario de los primeros fugitivos. Determinar la pertenencia de los descendientes era una situación bastante compleja. Según la ley, la esclavitud se heredaba por línea materna, es decir, era esclavo el hijo de vientre esclavo. Las formas jurídicas sobre la condición servil que la legislación indiana heredó de las Siete Partidas decía que: es siervo quien nace de hombre libre y de mujer esclava. María Embondo, quien huyó de la esclavitud cuando la estancia en donde servía fue quemada por los cimarrones, decía con frecuencia a sus hijos que eran esclavos de don Ilario Márquez y que no fuesen a otra casa si les desbarataban el palenque. Su nieto Antonio decía que cuando su abuela María Embondo jugaba con sus hijos les contaba quienes eran sus amos. A su vez, María Blanca estando próxima a morir dijo a sus hijos de quiénes eran esclavos para "en caso de que los cogiesen los blancos" supiesen a donde dirigirse. ${ }^{44}$ Igualmente, cuando Magdalena Malemba murió en el palenque, antes de expirar dijo "a

\footnotetext{
${ }^{42}$ Price, introducción a Sociedades cimarronas, 29.

${ }^{43}$ Ibid.

${ }^{44}$ Archivo Histórico Nacional, Madrid, leg. 1612, no. 1 s.f., fols. 48v-51 (en adelante citado como AHN).
} 
sus hijos y nietos que supiesen que si en algún tiempo los cogiesen los españoles que supiesen y estuviesen advertidos que eran esclavos del capitán don Juan de Heredia y doña Juana de Castro o de sus herederos" por ser ella esclava de los susodichos de cuyo poder se huyó y se fue al palenque. ${ }^{45}$

Pero había circunstancias por las cuales la línea materna se perdía en el tiempo o al palenque llegaban noticias de la rudeza de ciertos propietarios lo que llevaba a los cimarrones a cambiar el origen de su pertenencia. En ocasiones, ofrecían información contraria a las autoridades cuando creían que iban a tener una mejor situación con otros propietarios. Juana y Magdalena, negras criollas de los palenques, hijas de Francisca y Jacinta su nieta, descendientes de Lucía Angola, tuvieron conocimiento que habían pasado a propiedad de doña Francisca Bravo por donación que ésta recibió. A pesar de reconocer quien era su nueva propietaria negaron bajo juramento que doña Teresa Bravo fuera su ama porque se rumoraba en el palenque que la dicha señora, según su apellido era muy brava, castigaba y azotaba mucho. ${ }^{46}$

Una de las funciones de los capitanes de los palenques era reunir a sus habitantes y recordarles quiénes eran sus amos para que supieran a dónde ir en caso de ser capturados. Así lo hacía Domingo Criollo capitán de los palenques de las Sierras de María. Es probable que con esta medida quisiese garantizar una futura estabilidad, en caso de disolución del palenque y trataba de mantener de esta forma las relaciones de confraternidad que se establecían entre los esclavos de un mismo propietario. Con la persecución a los palenques uno de los graves problemas que enfrentaban era la dispersión, por lo tanto, al tener presente quién era el amo se abría la posibilidad de que al ser capturados fueran reunidos por las autoridades. Pablos, de casta angola oyó decir a Lucía Angola, en el palenque la Magdalena quién era su ama, "particularmente el día en que Domingo Angola hizo juntar toda la gente del dicho palenque y que cada uno fuese diciendo quien era su amo." De esta forma, "el capitán Domingo Angola decía a los esclavos los amos que tenía cada familia para que lo supiesen, por si en algún tiempo fuesen aprehendidos... y no fuesen a otro dueño." 47

Es muy probable que este hecho tuviese que ver con la necesidad de mantener unidas las familias de los cimarrones y de hacer más llevadera la vida en esclavitud, en caso de que

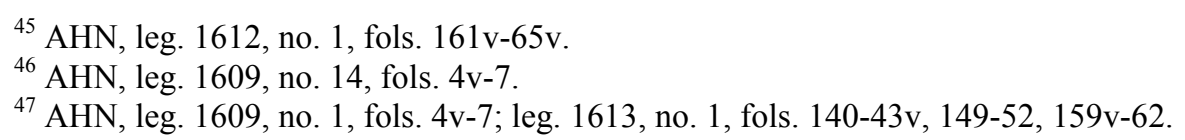


tuvieran que regresar a sus antiguos propietarios. Se sabía que si no podían identificarse los dueños, los cimarrones pasaban a propiedad del rey y eran embarcados y vendidos en otros reinos; por ende las familias serían dramáticamente disueltas y sus miembros dispersos en varios sitios, muchas veces lejanos.

Asimismo, la determinación del dominio sobre los cimarrones tenía relación con las formas como éstos se organizaron socialmente en el palenque. En las declaraciones que los fugitivos presentaron ante las autoridades era reiterativa la costumbre de agruparse en el palenque de acuerdo con las familias a las cuales pertenecían los primeros cimarrones escapados de la esclavitud. Era habitual entre ellos que quienes habían sido esclavos de los mismos amos se tratasen en el palenque como compañeros, como si fuesen hermanos. Los cimarrones pertenecientes a un mismo dueño solían agruparse en el palenque y tomar su apellido. De esta manera, las familias se reconocían por el nombre de sus antiguos amos. Cuando llegaba al palenque un negro recién escapado, se le indagaba por sus amos y, si en el palenque había antiguos esclavos de éstos, entonces, lo agasajaban y llevaban a sus casas como compañero; lo acogían en ellas y lo querían más que a un hermano. Lucía una criolla del palenque la Magdalena declaró ante las autoridades que era "costumbre en dichos palenques que en yendo a ellos algún negro o negra, sabiéndose su amo, la familia que había de aquel dueño le recogía y agasajaba teniéndole como compañero." 48

Los sistemas que usaban los cimarrones para establecer lazos de unión y hermandad confundían a los representantes de la autoridad que no entendían su significado y las implicaciones que tenían. Algunos miembros de los palenques se llamaban hermanos por haberse bautizado juntos. Esta fraternidad era incomprensible para jueces e inquisidores. En una oportunidad, para resolver un dilema de esta índole, fue llamada ante el comisario de la Inquisición de Panamá, a dar testimonio, una criolla negra llamada Leonor, quien declaró que María Josefa su madre, era hermana de María Blanca y que esta hermandad se debía a que se habían bautizado juntas, pero que, en verdad, María Blanca, era hija de María Josefa y hermana de la declarante. Todas ellas habían vivido en los palenques de las Sierras de María. ${ }^{49}$

Estas formas de parentesco eran muy importantes en la organización social de los palenques. Evidencian las nuevas construcciones sociales de los cimarrones que se

\footnotetext{
${ }^{48}$ AHN, leg. 1613, no. 1, fols. 146-49, 152-55, 159v-66v, 171-3, 180-3v, 203v-7v, 214-8v.

${ }^{49}$ AHN, leg. 1612, no. 1 , fols. $57 \mathrm{v}-61$.
} 
fueron gestando en la vida de las estancias y en las residencias señoriales del área urbana, desde donde escapaban los esclavos.

Esta idea de parentesco y organización social de los palenques concuerda con la apreciación de que cuando la gente vive en proximidad inmediata, sin ser parientes consanguíneos, tiende a tratarse como parentela y termina considerándose como tal. Los lazos sociales, en suma, son más importantes que los lazos de sangre.

Además de estas formas singulares de fraternidad, se reconocieron los lazos de parentesco por medio de la consanguinidad. Estos constituyeron el sentido de pertenencia a una parentela y de vínculos familiares. Los cimarrones hablaban de sus hermanos por línea paterna o materna, de sus abuelos, tíos, primos, sobrinos y nietos, según filiaciones de consanguinidad y con la denominación hispana para determinar relaciones de parentesco. Juan Salvador, un criollo negro nacido en los palenques de las Sierras de María, hijo de María Josefa, declaró tener dos primos hermanos, hijos de su tía Blanca, llamados Pachito y María. También, se refirió a sus sobrinos, hijos de Magdalena su hermana, cuyos nombres eran Esperanza y Felipe y a un tío nombrado Mateo, tuerto de un ojo. Igualmente, tenía otros hermanos y parientes y conocía algunos nietos de Magdalena Malemba. ${ }^{50}$

Estos vínculos sociales fueron construcciones propias de los palenques y demuestran que los grupos se organizaron en sus poblados sobre la base de lazos asociados con la vida de las estancias, mucho más que en términos de filiaciones tribales africanas. Los cimarrones fueron capaces de convertirse en valerosos guerreros $\mathrm{y}$, al mismo tiempo, elaborar formas culturales y sociales sobre la base de las que ellos y sus padres africanos habían establecido en las estancias y familias esclavistas patriarcales.

Sin embargo, es preciso resaltar que algunas formas tradicionales africanas de organización social, pudieron preservarse, si las condiciones así lo permitían. Estas llegaron a combinarse con influencias culturales europeas $\mathrm{y}$, especialmente, adaptaciones locales. Estos elementos africanos se evidenciaron y son reconocibles. Los africanos procedentes de las mismas comunidades tribales, es decir, pertenecientes a una misma "casta," como se expresaba en ese entonces el origen étnico, tenían comunicación entre sí en su misma lengua y de ser posible se agrupaban de acuerdo con su origen étnico y lingüístico. Fue así como Luisa Malemba y Magdalena Malemba, compañeras y

${ }^{50}$ AHN, leg. 1612 , no. 1 , fols. $3-4,130-3$. 
esclavas de doña Juana de Castro escaparon juntas a uno de los palenques de las Sierras de María. Allí se unieron como "mancebas" y tenían "amistad ilícita" a la vez con Antonio Malemba, quien tenía por sobrenombre el de Calenguí (nombre que llevaba en su tierra). Por lo demás, María de la $\mathrm{O}$, de casta angola, declaró que "ésta como parienta y de su casta y una propia lengua tenía conversación con el dicho Antonio Calenguí." 51

A pesar de la heterogeneidad de los palenques es probable que otros aspectos de las formas de relación social africanas se conservaran. Aunque es difícil afirmar qué tan arraigada estuvo la poligamia y qué tan generalizada pudo haber sido, porque los documentos sólo dan cuenta de algunos casos, si es posible señalar que esta práctica cultural africana fue ejercida por los cimarrones, algunas veces, apoyada en un origen étnico común.

Una de las dificultades que enfrentaron los capturados cuando en los interrogatorios les preguntaban sobre su origen familiar se derivaba del hecho de que en ocasiones, el abuelo había tenido relaciones paralelas con más de una compañera. Por ello, los nietos de los primeros fugitivos se contradecían en sus declaraciones. Esto le sucedió a Francisco, nieto de Antonio Malemba cuyo abuelo "había estado amancebado a un mismo tiempo y dentro de una misma casa" con Magdalena Malemba y Luisa Malemba; por esta razón consideraba a las dos como sus legítimas abuelas. ${ }^{52}$

La poliandria, como forma femenina de poligamia también se presentó en los palenques de las Sierras de María. No es posible afirmar con qué frecuencia ocurrió, por la falta de información de las fuentes primarias, pero el caso de Lucía Angola, quien fue mujer de Agustín Angola y de Domingo Endongo parece comprobar la situación. Sólo se sabe a ciencia cierta que de la unión de Lucía Angola con Agustín hubo dos hijas: Serafina y Francisca. Al parecer tuvo otros hijos pero no se puede distinguir si fueron de él o de Domingo. A su vez Francisca, la hija de Lucía fue mujer de Domingo Angola, capitán de los palenques y de Juan Embuyla. ${ }^{53}$ Este núcleo familiar es un buen ejemplo de la constitución en los palenques de un grupo de origen bantú, puesto que angolas, endongos y embuylas forman parte de esta comunidad cultural.

\footnotetext{
${ }^{51}$ AHN, leg. 1612, no. 1, fols. 24-9v.

${ }^{52}$ AHN, leg. 1612, no. 1 , fols. $139 \mathrm{v}-43$.

${ }^{53}$ AHN, leg. 1609 , no. 14; leg. 1612, no. 1; leg. 1613, no. 1.
} 
Estas características no fueron óbice para que estas agrupaciones fueran formaciones heterogéneas de diversos orígenes. Ello quiere decir que en los palenques se combinaron tradiciones culturales africanas, hispanoamericanas e indígenas que hicieron de los palenques un conglomerado étnico de construcciones culturales y sociales novedosas. En el de San Miguel, uno de los más importantes de las Sierras de María, por ejemplo, había negros congos, angolas, minas, ararás, criollos nacidos en los palenques y criollos de la Provincia de Cartagena. En otros lugares, además de los grupos mencionados, había mulatos, indios y mestizos.

En conclusión, puede afirmarse que los palenques no fueron comunidades homogéneas; representaron una variedad de orígenes africanos con la diversidad cultural que esto implicaba. También, representaban diferentes adaptaciones personales a las situaciones locales lo que incluía distintos grados de criollización. Gran parte del conocimiento cultural, necesario para la adaptación física de los cimarrones, ya se había desarrollado en el Nuevo Mundo.

Cuando los ancestros de los cimarrones escaparon de las minas, los hatos, las estancias y las casas señoriales llevaron consigo un legado cultural que había tomado forma en la esclavitud; portaron con ellos principios organizativos, económicos y religiosos que dieron pie a formas novedosas de supervivencia en los palenques. El sincretismo interafricano con mayor o menor influencia europea e indígena y las adaptaciones locales fueron casi siempre el proceso central para forjar nuevas formas de cultura afroamericana. 